\title{
A Discrepancy Analysis of Authentic Assessment Implementation In EFL Classroom of Senior High School In Badung Based On Curriculum 2013
}

\author{
I.G. Kardiana ${ }^{1}$, A.A.I.N. Marhaeni ${ }^{2}$, N.M. Ratminingsih ${ }^{3}$ \\ Program Studi Pendidikan Bahasa Inggris, Program Pascasarjana \\ Universitas Pendidikan Ganesha \\ Singaraja, Indonesia \\ e-mail: gedekardiana28@gmail.com @pasca.undiksha.ac.id \\ made.ratminingsih@undiksha.ac.id @pasca.undiksha.ac.id \\ ngr.marhaeni@undiksha.ac.id @pasca.undiksha.ac.id
}

This study aimed at investigating and describing the discrepancy of authentic assessment implementation in EFL classroom of SMAN 1 Abiansemal based on the 2013 Curriculum and the teacher's belief on the authentic assessment implementation. This is an evaluative study, especially educational evaluation. The subjects of this research are three EFL teachers in SMAN 1 Abiansemal. The data were collected by using four methods of data collection, namely documenting, observation, in depth interview and questionnaire. Based on the methods of data collection, there were instruments utilized such as observation sheet, teacher's belief questionnaires, and interview guide. The data obtained from the observation sheet and questionnaire of teacher belief were analyzed and calculated by using Ideal Theoretical Reference Criteria. From the data analysis it was found that (i) the discrepancy of authentic assessment implementation in EFL classroom of SMA Negeri 1 Abiansemal based on the curriculum 2013 is categorized into narrow, specifically, self assessment is categorized into narrow, portfolio assessment is categorized into moderate, performance assessment is categorized into very narrow. and project assessment is categorized into narrow and (ii) The teachers' beliefs about authentic assessment implementation is categorized into very positive. This results means that the implementaion of authentic assessment in Curriculum 2013 can not be achieved ideally.

\section{Keywords: authentic assessment, curriculum 2013, discrepancy analysis, EFL classroom, teacher's belief}

\section{INTRODUCTION}

The quality of a country is determined by the quality of education. It becomes a challenge for educators on how to design and to manage the education. The education should be meaningful for the students. Meaningful education helps people survive, but unmeaningful education just burden the students (Buchori in Marhaeni, 2005:1).

The Indonesian government realizes how important the education for the development of the country is. It leads the government does several innovative steps. One of the most crucial steps done by the government is the changing of curriculum. The reason of the changing is the era demand. During a decade, Indonesian has changed 4 times the curriculum. It starts from curriculum 1994, competency based curriculum, school based curriculum, and lastly curriculum 2013. Even though, curriculum 2013 is not implemented in all schools today. There are several schools pointed by the government to implement this curriculum.

School-Based Curriculum is developed to be Curriculum 2013 based on the thought of future challenges in 21th Century which is identified by the age of knowledge, knowledgebased society, and future competency (Disdikpora Kabupaten Badung, 2012:3). Curriculum 2013 promises to produce productive, creative, innovative, and characterized human resources. By creativity, they are able to innovate productively to respond future challenges which become more complicated and complex.

There are six reasons of Curriculum 2013 changes (Setiawan dalam Ratnadi, 2015:3). First is revision of methodology. The implementation of educational methodology which is no longer in the form of learning for graduation, but holistic education which concerns on 
competencies of social, nature, character, love of Indonesian culture-language. Second is remanagement of school curriculum. It is divided into national, local and school curriculum level, so it can trigger the output of education who can respond the needs of human resources. Third is curriculum of subjects are integrated into the same core competency from one subject to other subjects with four demands of graduate competency standard that is core competency 1 (KI 1) about religious spiritual intelligence, core competency 2 (KI 2) has good social competency, core competency 3 (KI 3 ) has an adequate knowledge and core competency 4 (KI 4) has skills/expertise. Therefore, whoever the teacher, whatever the subjects should produce religious students who are able to socialize well, intelligent, skillful and have life skills. Fourth is the result of research and review of school based curriculum 2006 which gives full autonomy to the school was failed since there was almost no school able to develop their own curriculum, the fact showed that the schools only copy and paste national curriculum proposed by BSNP. Fifth, it was found that some intelligent students were found had bad attitude and did not reflect students' attitude, the school should be brave no to pass the students. Six, in curriculum 2006, the wanted attitude and character in the learning is only insertion, so in Curriculum 2013 those are showed in real and demanded to be standard of graduate competency.

One of the crucial issues in Curriculum 2013 is assessment system. Through PERMENDIKBUD 104 Year 2013 about the assessment of students' result of learning, the government regulates the assessment system applied and needed in this curriculum. in article 1 point 1, it is stated that the assessment of learning result by eductor is the process of collecting information/ evidence about the achievement of students' instruction in spiritual and social acts competency, knowledge competency, and skill competency done systematically and manageably along and after instruction process.

Furthermore, in article 2 point 1 , it is stated that the assessment of learning result by educator is done in the form of authentic and non authentic assessments. Authentic assessment approach is the main approach in assessing learning result by the educator. The form of authentic assessment covers the assessment based on observation, field project, postfolio, project, product, journal, laboratorium working, performance, and self-assessment. Meanwhile, the non-authentic assessment covers test, daily examination, and examination.

To know how the teacher implements the assessment, an observation is done in SMAN 1 Abiansemal in English subject. It is one of the schools in Badung Regency which implements Curriculum 2013. There are three main reasons this school was selected. First, it is located in Badung Reegency where it is one of developed in Bali. Second, it is one of advanced school in Badung Regency. Of course, education is managed ideally. Third, as the school located in the most famous tourism area, this school demands high standard English mastery for their students. There are certain activities or programs done by the school to exercise students' English competency.

From the observation, four crusial informations acquired. First, the teacher dominantly uses test and examination to assess students' learning. Multiple choice test is still trend to be implemented. Second, the assessment is just done on knowledge competency. There is less attention on social, spiritual, and skill competencies. Third, the teacher never applies authentic assessment, such as portfolio assessment, self-assessment, project assessment, performance assessment, and journal. Fourth, teachers' consideration in choosing assessment is based on the practicality.

The phenomena of assessment implementation observed are of course different from the ideal assessment expected by the government. It seems that there is a gap between the ideal assessment and assessment in reality. This gap potentially causes problems on the quality of the Indonesian education. Thus, changing on paradigm of teachers' thinking should be done as soon as possible. It can lead the teacher to do assessment based on the government expectation. As the consequence, the improvement of educational quality can be true.

This research aims at evaluating the gap between the authentic assessment applied in Curriculum 2013 used in English subject. The analysis used discrepancy model evaluation developed by Provus (1970). 
Based on the previous explanation, there were two problems problems investigated as follows.

1. To what extent is the discrepancy of authentic assessment implementation in EFL classroom of SMA Negeri 1 Abiansemal based on the curriculum 2013?

2. What are the teachers' beliefs about authentic assessment implementation?

\section{RESEARCH METHOD}

This research is categorized into evaluative study with discrepancy model proposed by Provus (1970). It aims at analyzing and describing to what extent the discrepancy of authentic assessment implementation in EFL classroom of SMAN 1 Abiansemal based on the 2013 Curriculum and the teacher's belief on the authentic assessment implementation. the subjects of the research were three EFL teachers in SMAN 1 Abiansemal.

The data were collected by using four methods of data collection, namely documenting, observation, in depth interview and questionnaire. Based on the methods of data collection, there were instruments utilized such as observation sheet, teacher's belief questionnaires, and interview guide. The data obtained from the observation sheet and questionnaire of teacher belief were analyzed and calculated by using Ideal Theoretical Reference Criteria.

\section{FINDINGS AND DISCUSSION}

Discussion of the findings is divided into two, discussion of the (1) discrepancy of authentic assessment implementation in Curriculum 2013 and (2) teachers' belief in implementing authentic assessment.

Based on the result of data analysis, it is known that the discrepancy of authentic assessment implementation is narrow. This score is 36.07 categorized into narrow discrepancy. In detail, the implementation of portfolio assessment is categorized into moderate discrepancy, self-assessment is categorized into narrow discrepancy, performance assessment is categorized into very narrow discrepancy and the project assessment is categorized into narrow discrepancy. Based on this finding, it can be concluded that government expectation in implementing authentic assessment can not be achieved ideally by the EFL teachers in SMAN 1 Abiansemal. However, the discrepancy between the expectation and implementation of authentic assessment is small.

In detail, some descriptions of every authentic assessment implementation in SMA Negeri 1 Abiansemal can be seen as follows. Since the implementation of portfolio assessment is categorized into moderate discrepancy, it means that there was average difference between the government expectation and the implementation of authentic assessment in the English class in SMA Negeri 1 Abiansemal. Among other authentic assessment types, portfolio assessment has the widest discrepancy. It needs some improvement in implementing it. The classical problem faced by the teachers regarding to the portfolio assessment is collecting the assessment itself. They need to have tidy report of every single assessment since it takes very long time to be finished. Sometimes, they lose some of the assessment and it takes more concern on what action that should be done about that case.

Self-assessment is categorized as narrow discrepancy. It means that there is only small discrepancy in implementing it. Although the discrepancy is narrow, but there should be more improvement on this assessment since the teachers still think that the involvement of the students in the assessment is bad. They did this assessment is actually because the supervisor and the principal told so. The self-awareness of implementing self-assessment and having confidence on the implementation of this assessment is important in order to achieve the government expectation optimally.

Performance assessment is categorized as very narrow discrepancy. It means that the implementation of this assessment by the English teacher in SMA Negeri 1 Abiansemal is nearly closed to the government expectation. In addition, it is the authentic assessment which has the lowest discrepancy among others. Performance assessment is mostly used by the EFL teachers in SMAN 1 Abiansemal especially in productive skills (speaking and writing). Recently, the teachers also apply it in receptive skills (reading and listening) as a ways to test 
their students' actual ability. The use of paper pencil test is viewed less holistic because there is luckiness factor in answering questions.

The last but not the least, the project assessment is categorized into narrow category. The discrepancy is as as the self-assessment. It means that there was still low difference between the government expectation and the real situation of project assessment implementation in English class of SMA Negeri 1 Abiansemal. This situation is caused by the less-experiences of the teachers in implementing it. Actually, this assessment has been implemented previously, however since the way to assess is considered hard, the teacher prefer to use performance assessment than it. Project assessment is implemented in group, it makes the teacher has difficulty in giving individual score to the students. The problems were found in the process of planning, execution and analysis and reporting phases.

This finding indicated that there was a gap between what had been expected by the government and what was implemented by the teacher. This gap could be a source of problem since there was misunderstanding of the teachers, especially English teachers in implementing authentic assessment in the school. If this condition continues so the expectation of the government will never be achieved. Therefore, treatment should be done to fix this condition. In order to give effective and efficient treatment, the factors causing this condition should be identified firstly. Those factors could be identified by knowing the teacher's understanding and belief on their authentic assessment implementation. By knowing their understanding and beliefs, the treatment could be started from these findings.

In addition, this results seem to be reflection for the EFL teachers on measuring how competent they are in implementing curriculum 2013 expectation, especially in assessment parts. As being implied in Permendikbud 81 A tahun 2013 and Permendikbud 103 tahun 2014, the use of authentic assessment aims at providing meaningful and quality learning experiences to the students. Authentic assessment seems to be alternative of the assessment problems focusing merely on paper-pancil test faced by the Indonesian government previously.

The discrepancy which occurs is caused by the features of authentic assessment itself. The features are totally different from the paper pencil test. There are five features considered as the factors influencing it. First, authentic assessment is on going process. Second, less knowledge about authentic assessment. Third, authentic assessment measures three domains, namely: cognitive, afective, and psychomotor which is different from test which just measure cognitive. Forth, the complexity of authentic assessment which needs special and intense training for the teachers. Fifth is the difficulty in constructing criteria for the competency that want to be achieved.

The discrepancy occured in implementing authentic assessment can be explained by Permendikbud $81 \mathrm{~A}$ of 2013 about the consideration of authentic assessment implementation. There are five things to consider in designing authentic assessment, namely 1) the assessment is intended to measure students' achievement of the standard of competency in core competency 3 about knowledge and core competency 4 about skills, 2) the assessment should be criteria-based. It means that the students are assessed based on what they have learned during learning and not to compare an individual with the group, 3) the system of assessment is an on-going assessment. It means that the assessment is done based on the required indicators and the result is used to determine the achieved and unachieved competencies as well as to know students difficulties in learning the topic, 4) the result of an assessment is analyzed to know the following up action. The action can be a revision of the next learning, remedial program for the students who have not achieved the passing grade yet, and enrichment for those who have achieved the passing grade, and 5) the assessment system should be based on the students' learning experiences. It means that the students should have experiences of completing a project during the learning process before teacher design a project assessment to measure their competencies toward a certain topic. Besides that, in order to achieve these principles, the teachers have to follow the three stages of assessment, namely the planning, execution and analysis and reporting.

Based on the explanation of Permendikbud 81A of 2013, the teachers violated the importance of the three stages of the authentic assessment implementation. It could be seen from the result of the questionnaires which indicated the teachers only focused on the 
execution of the assessment and neglected the planning and analysis and reporting process. Neglecting the planning of the assessment could cause the assessment is not valid because it was made randomly. Moreover, neglecting the analysis and reporting will make the assessment is meaningless, since the result of the assessment is not only as the result of students learning but also as a reflection of the teaching learning process. Therefore, if the teachers neglected this process, so there will not be improvement of the teaching learning process.

Besides that, not involving students in the process of assessment also neglected the opportunity of the students to be more creative and critical. The argument of involving the students might decrease the subjectivity of the assessment could be tackled by making a good criteria-based assessment. So, the teacher should provide good instrument for the students to make their own assessment, take for example in self-assessment, in order to avoid the subjectivity. These good instruments will decrease the subjectivity itself. The only teacherbased assessment can be less objective if there was not instrument at all. Therefore, involving the students in authentic assessment is good since it can make them to be more critical. Involvement of the students' parent is also a creative process, so the parents will have a responsibility of their children learning.

The use of authentic assessment in the context of learning is important to be done especially in modern education as today. Boud and Falchikov (2005) suggest that educators need to move from traditional (paper and pencil) assessment that focuses on specifics, standards and immediate outcomes to more sustainable assessment that can aid students to become more active learners not only in managing their own learning, but also assessing themselves to life beyond the end of the course. Here, it is suggested that the implementation of authentic assessment can be a solution in the complex demand of education today. If it is connected to the finding, it seems that the authentic assessment applied by the teacher is not able to make the students manage their learning and assess their learning. As the consequence, the expectation of authentic assessment implementation can not be achieved by the EFL teacher.

The data analysis shows that the teachers in SMAN 1 Abiansemal do not maximally implement authentic assessment. It seems that the teachers may get limited information about the students' learning. As being argued by Kankam, et al (2014), authentic assessment provides valuable information and improves students' learning regarding how effective a teacher's instructional strategies have been to date. Authentic assessment help teachers identify the level of understanding their students have reached, become aware of students' strengths and weaknesses, and to monitor their current progress during the learning process. It can be imagined if authentic assessment applied ideally, students' learning becomes meaningful. Unfortunetly, authentic assessment did not applied ideally so it might be a factor causing the low quality of students.

The finding of this research can be considered to complete previous researches that have been done previously regarding to the implementation of Curriculum 2013 in Indonesia. The first research is conducted by Ratnadi (2015) who conducted evaluative study which analyzes the readiness of the teacher in implementing Curriculum 2013. Based on the study, it was found that elementary school teachers in Rendang Subdistrict are ready to implement curriculum 2013 viewed from context, input, process, and product variables. Even though, there are some things which need to be improved. This result of this research complete the previous research in term of assessment implementation. This research shows low discrepancy, it means that the teachers have good competent in implementing authentic assessment in Curriculum 2013. It makes Indonesia is actually confident to implement Curriculum 2013 since the teachers are ready to implement it generally and specifically in terms of assessment.

In contrast, Riptiani (2015) figured out a description of the effectiveness of several components, like context, input, process, and product to support the implementation of curriculum 2013 based on CIPP at government elementary schools in the rural areas in Badung Regency. She concluded that the elementary schools in the rural areas in Badung Regency are found ineffective to implement curriculum 2013. Based on these findings and 
compared to the finding of the present study, it can be concluded that the implementation of Curriculum 2013, in terms of its readiness, assessment, and school level implementation, need some improvement, both in level of elementary and high school. The improvement directs to the ideal Curriculum 2013 implementation.

The finding of this research is also identical to result of research done by Bordoh, et al. (2015). In the study, they discovered that knowledge in authentic assessment was relatively poor. Clearly, there were noticeable gaps and variations between the teachers' conceptions and theoretical knowledge of authentic assessment and their relevant practices in the classrooms. It is same as the result of current research in which there is a gap between authentic assessment expectation and implementation. In addition, the EFL teachers observed in this research do not have good knowledge and understanding of authentic assessment. It is predicted as the main factors causing the discrepancy occurs.

Based on the finding of this research, there should be an evaluation on the implementation of authentic assessment. even though the discrepancy is narrow, but for the perfectness of authentic assessment implementation, some steps should be done. First, workshops on how to implement authentic assessment in EFL (not in general for all subjects) should be done more frequently. As being known that, the workshops that had been done by the government just exercise the teacher on general implementation of authentic assessment, not specifically on EFL. Second, the government should provide the teachers with fix authentic assessment implementation in each language skill per grade. In other words, a practical authentic assessment instruments are given. It can help teacher simplify their jobs. By doing those steps, it is expected the discrepancy can be eliminated.

Furthermore, based on the result of data analysis, the teachers' belief in implementing authentic assessment is categorized into very positive. Four dimensions of teachers' belief (mastery learning, assessment authenticity, teachers' understanding on authentic assessment, and assessment continuity) in all grades are categorized into very positive. Meanwhile, for curriculum expectation dimension, all teachers are in positive category. For students' contribution in assessment dimension, the tenth and eleventh grades EFL teacher are categorized into very positive, but for the twelfth grade EFL teacher is categorized into positive. Finally, teacher's expectation to authentic assessment implementation dimension, tenth and twelfth grades EFL teachers are categorized into very positive and just eleventh grade EFL teacher is categorized into positive category.

In mastery learning mastery learning, the result was "very positive". It indicated that all of the English teachers believed that they had improved students' achievement by the implementation of authentic assessment. The implemented authentic assessment was designed based on the available syllabus so the learning process was in line with the purpose of the learning. This finding showed that the perspectives of the teachers have been in line with the purpose of authentic assessment which is not only as the evaluation of learning process but also as the trigger to improve students' learning achievement.

In terms of the authenticity of the assessment, the score was categorized into "very positive". It indicated that all of the teachers believed that they had made up the assessment by using authentic materials. The teachers believed that the assessment should be made up as authentic as possible. The more authentic the assessment the better result will be. They believed that assessment should be done to assess students' competency comprehensively. The assessment was also conducted to assess them individually as well as in group. The assessment should not be only conducted by the teacher. However, they did not believe to get the students involved in the assessment. They still believed that the assessment should be done only by the teachers in order to avoid subjectivity.

In terms of teacher's understanding on authentic assessment, all of the teachers believed that they had good understanding on the authentic assessment. The assessment is not only conducted to evaluate the result of the learning process but also the process of learning. They also believed that motivating the students to be more creative is the core of authentic assessment. They believed that what they know about authentic assessment is good.

In terms of assessment consistency, it was found that the score was categorized into "very positive". The teachers did assessment not only in the end of learning process but also 
throughout the process of learning. They believed that assessment should be done since the planning of learning process until the end of the process. They also believed that the result of the assessment does not only show students' achievement but also should be used as the feedback of the teaching learning process.

For curriculum expectation dimension, all teachers are in "positive" category. They believed that they had implemented the authentic assessment based on Competency Standard and Basic Competency stated in the syllabus. The assessment was also designed in order to assess written and spoken language of English. However, they did not know that they have to concern on Permendikbud 81A of 2013 concerning on the implementation of authentic assessment in Curriculum 2013. Even, they did not know this rules exist.

For students' contribution in assessment dimension, the tenth and eleventh grades EFL teacher are categorized into very positive, but for the twelfth grade EFL teacher is categorized into positive. It indicated that the teachers of tenth and eleventh grades believed that their students were involved in the process of assessment. Meanwhile, teacher of twelfth grade believed that the students' involvement in the authentic assessment implementation was not $100 \%$. The teacher of twelfth grade believed that by fully involving the students in the assessment, there would be tendency of subjectivity from the students. The students would give higher score than it supposed to be.

For teacher's expectation to authentic assessment implementation dimension, tenth and twelfth grades EFL teachers are categorized into very positive and just eleventh grade EFL teacher is categorized into positive category. It indicated that the tenth and twelfth grades teachers believed that they had maximum support in implementing the authentic assessment. Yet, teacher of eleventh grade believed there was some support that needed more. The support was in form of, school facilities and students' parent support. From the school, the teachers believed that all of the facilities and equipment provided to the English teachers could support their efforts in improving students' English competency. Besides that, they also believed that parents'support is also the most important thing to support the success of students' learning achievement. However, they did not believe in involving students' parent in the authentic assessment since this is the job of the teacher not the students' parent. The teachers also believed that they still need more improvement in order to get more knowledge and skill about implementing authentic assessment in English class.

This research discovers that the teachers' belief on the implementation of authentic assessment is categorized into very positive, it theoretically makes the teachers can ideally or almost ideally implement authentic assessment. Borg (1999) states that teachers' thought and instructional decision are influenced by their beliefs. It means positive belief of teachers on the implementation of authentic assessment should be in line with the quality of authentic assessment implementation. The teachers' belief on authentic assessment is categorized into very high, but their authentic assessment implementation is categorized into low discrepancy. It means that there is a slight gap between belief and implementation of authentic assessment. It should be that the teachers' authentic assessment implementation is categorized into very low discrepancy.

The linearity of teachers' belief and quality of assessment implementation is also supported by Munoz, et.al (2012). It is argued that belief is one of the factor influencing the classroom assessment. The choice of assessment and its application quality is caused by the belief of the teacher to chooses and implement certain assessment. It can be imply that the higher teachers' belief on assessment, the higher of their assessment implementation quality is. However, in fact, this research found on the contrary in which very positive belief of assessment, but low level discrepancy in authentic assessment implementation.

The result of this research seems to be in contrast to the theory of teachers belief. Theoretically, the teachers' belief level is in line with the quality level of authentic assessment. It is predicted that there are two main factors causing it. First, less knowledge and understanding owned by the teachers about authentic assessment. Second, the working hour for the teachers in which 24 hours needed in a week. It makes they can not implement authentic assessment ideally even though they believe that authentic assessment can bring positive effect for instruction. 
Based on the finding of these questionnaires it could be concluded that there were still some problems that should be fixed in order to eliminate the gap between government expectation and the real implementation of authentic assessment in English class in SMA Negeri 1 Abiansemal. In general, the teachers believed that they had implemented the authentic assessment correctly. However, there were some misunderstandings about the perception of authentic assessment by the teachers. Take for example; the teachers did not know Permendikbud $81 \mathrm{~A}$ of 2013. It is ironic since this minister regulation is the guideline established by the government for the entire teacher in Indonesia. If they did not know this regulation, so it is impossible for the teacher to achieve the government expectation.

This research is in contrast to the previous research done by Herrera (2010) . It is discovered that the utility of the model and the enhancements made to the multicultural assessment instruments. Depending upon what elements were chosen, between $18 \%$ and $23 \%$ of the variance explained in teacher's beliefs, attitudes and perceptions could be explained by their training, their community involvement, awareness of self, knowledge of subject and a positive approach to the institutional culture. The teachers' assessment implementation is mostly influenced by the teachers' belief on it. However, this research shows different result in which the teachers' belief in authentic assessment is very high, but the implementation of authentic assessment is in low discrepancy. The teachers' belief should be very low discrepancy.

By seeing the level of discrepancy of authentic and the level of teachers' belief, there should be a survey done by the government on the real problems faced by the teachers in real world. For example, the number of students in a classroom can be used as the consideration in implementing authentic assessment. the teacher believe that authentic assessment contributes to the learning, but the reality does not support it like the students' number. By knowing the factors, the government can evaluate and revise the Curriculum 2013 so that it is not too hard or difficult to be implemented by the teachers.

\section{CONCLUSION AND SUGGESTIONS}

Based on the reserach problems and the result of data analysis, there are two conclusions drawn. First,the discrepancy of authentic assessment implementation in EFL classroom of SMA Negeri 1 Abiansemal based on the curriculum 2013 is categorized into narrow. Specifically, the discrepancy in implementing self assessment is categorized into narrow, portfolio assessment is categorized into moderate, performance assessment is categorized into very narrow and project assessment is categorized into narrow. Second, the teachers' beliefs about authentic assessment implementation is categorized into very high. Four dimensions of teachers' belief (mastery learning, assessment authenticity, teachers' understanding on authentic assessment, and assessment consistency) in all grades are categorized into very high. Meanwhile, for curriculum expectation dimensioan, all teachers are in high category. For students' contribution in assessment dimension, the tenth and eleventh grades EFL teacher are categorized into very high, but for the twelfth grade EFL teacher is categorized into high. Finally, teacher's expectation to authentic assessment implementation dimension, tenth and twelfth grades EFL teachers are categorized into very high and just eleventh grade EFL teacher is categorized into high category.

Based on the findings, three suggestions are recommended. First, it is suggested to the $E F L$ teachers to implement authentic assessment well in the classrrom. Actually, the teachers have very high belief on the implementation of authentic assessment, but the discrepancy is narrow. It seems that there is a reluctancy to apply ideally authentic assessment in the classroom. Second, for the government it is suggested to give more training on the implementation of autehntic assessment in Curriculum 2013 especially for portfolio assessment. It is because the discrepancy in this assessment is categorized into moderate. Third, for the other researchers, it is recommended to do further research to investigate the factors causing the discrepancy. The factors investigated are teachers, schools, and government. Therefore, the holistic information about the factors causing discrepancy can be known. 


\section{REFERENCES}

Bordoh, A., Eshun, I., Quarshie, A.M., Bassaw, T.K., \& Kwarteng, P. (2015). Social studies teachers' knowledge base in authentic assessment in selected senior high schools in the central region of ghana. Journal of Social Science and Humanities, 1(3), 249-257

Borich, G.D. (2007). Effective teaching methods: Research-based practice. New Jersey: Pearson Merril Prentice Hall.

Borg, S. (1999). Teachers' theories in grammar teaching.ELT Journal 53(3), 157-167.

Boud, D. and N. Falchikov. (2005). Redesigning assessment for learning beyond higher education. Res. Dev. Higher Educ, 28 (1) ,34-41.

Disdikpora Kabupaten Badung. (2012). Training manual of curriculum 2013 implementation. Manual for the English Teacher Training in Implementing Curriculum 2013.

Herrera, J.C. (2010). Teacher beliefs and practices: Their effects on student achievement in the urban school setting. Published dissertation: Kansas State University.

Kankam, B., Bordoh, A., Eshun, I., Bassaw, T. K., \& Korang, F. Y. (2014). Teachers' perception of authentic assessment techniques practice in social studies lessons in Senior High Schools in Ghana. International Journal of Educational Research and Information Science, 1(4), 62-68.

Marhaeni, A.A.I.N. (2005). Pengaruh asesmen portifolio dan motivasi berprestasi dalam belajar bahasa inggris terhadap kemampuan menulis dalam bahasa inggris. Unpublished Dissertation: Universitas Negeri Jakarta.

Munoz, A.P., Palacio, M., \& Escobar, L. (2012). Teachers' Beliefs About Assessment in an EFL Context in Colombia. Universidad Nacional de Colombia, Facultad de Ciencias Humanas, Departamento de LenguasExtranjeras.Profile (Vol. 14, pg 143-158. Bogotá, Colombia.

Permendikbud 81 A year 2013 tentang Implementasi Kurikulum.

Permendikbud 66 year 2013 tentang Standar Penilaian Pendidikan.

Permendikbud No 103 year 2014 tentang Pembelajaran Pada Pendidikan Dasar Dan Pendidikan Menengah.

Permendikbud No 104 year 2014 tentang Penilaian Hasil Belajar oleh Pendidik pada Pendidikan Dasar dan Pendidikan Menengah.

Permendikbud 53 year 2015 tentang Penilaian Hasil Belajar Oleh Pendidik Dan Satuan Pendidikan Pada Pendidikan Dasar Dan Pendidikan Menengah.

Ratnadi, NWS. (2015). Studi evaluatif tentang kesiapan mengimplementasikan kurikulum 2013 di SD se Kecamatan Rendang. Unpublished Thesis. Singaraja: Ganesha University of Education.

Riptiani, K.M. (2015). Studi evaluasi implementasi kurikulum 2013 ditinjau dari cipp pada sekolah dasar negeri di wilayah pedesaan kabupaten badung. E-journal PGSD Universitas Pendidikan Ganesha. 